\title{
Siew New Disease Reports \\ First report of the molecular identification of a phytoplasma associated with dieback disease of papaya in Sri Lanka
}

\author{
S. Abeysinghe ${ }^{1 *}$, W.G.S.M. Kumari ${ }^{1}$, I.M.M. Arachchi ${ }^{1}$ and M. Dickinson ${ }^{2}$ \\ ${ }^{1}$ Dept. of Botany, Faculty of Science, University of Ruhuna, Matara, Sri Lanka; ${ }^{2}$ School of Biosciences, University of \\ Nottingham, Sutton Bonington, UK
}

*E-mail: saman@bot.ruh.ac.lk

Received: 17 Jan 2014. Published: 14 Apr 2014. Keywords: Carica papaya, Monaragala, 16SrI phytoplasma

Papaya (Carica papaya) is a very popular fruit crop in Sri Lanka, grown as a home garden and commercial crop for local and export markets. Papaya is commercially cultivated in Sri Lanka in about 8,000 ha with production of about 32,000 tonnes/year. As elsewhere, phytoplasma diseases have become a threat to the papaya crop in Sri Lanka. During November 2012, dieback-like symptoms were observed in papaya fields at Monaragala, Uva Province, in Sri Lanka. Symptoms in the field initially included a bright yellowing of the upper young leaves (Fig. 1a) that progressively evolved to tip necrosis in the tender leaves (Fig. 1b), followed by drying of the upper leaves and eventual death of the whole plant (Fig. 1c). Moreover, diseased plants exhibited discolouration of the vascular tissues, abnormal growth and shapes of fruits and premature fruit fall.

Total genomic DNA was extracted from the midribs of fresh leaf samples $(1 \mathrm{~g})$ from four plants with symptoms and two symptomless plants using the DNeasy Plant Mini Kit (QIAGEN, UK) according to the manufacturer's protocol. Phytoplasma rDNA was amplified with the universal phytoplasma primer pairs $\mathrm{P} 1 / \mathrm{P} 7$ in the first round of polymerase chain reaction $(\mathrm{PCR})$, and R16F2n/R16R2 in a nested PCR (Dickinson et al., 2013). Amplifications of the $16 \mathrm{~S}$ rDNA were performed in $25 \mu \mathrm{l}$ reactions using Ready-To-Go PCR beads ${ }^{\mathrm{TM}}$ (Amersham Pharmacia Biotech, UK) in a TECHNE TC-3000 thermocycler, and resulted in PCR bands of approximately $1.2 \mathrm{~kb}$ from symptom-bearing plants but not from the symptomless papaya plants (Fig. 2). Three representative nested PCR products were purified (PCR Cleanup kit, Sigma, UK) and directly sequenced. A phylogenetic tree (Fig. 3) was constructed based on the $16 \mathrm{~S}$ rDNA consensus sequence using the neighbour-joining method with default values and 1000 replicates for bootstrap analysis (MEGA version 3.1). The partial 16S rDNA sequences of the three representative phytoplasma isolates shared $100 \%$ sequence identity with each other. The BLAST analysis of the consensus sequence of the Monaragala papaya dieback phytoplasma (GenBank Accession No. KJ027722) revealed 99\% sequence identity with that of phytoplasmas of group 16SrI ('Candidatus Phytoplasma asteris'). Acosta et al. (2011) previously reported a phytoplasma from group $16 \mathrm{SrI}$ associated bunchy top-like symptoms of papaya in Cuba. Moreover, phytoplasmas belonging to different $16 \mathrm{Sr}$ groups have been identified in papaya, particularly in the Asian continent including group 16SrII ('Candidatus Phytoplasma aurantifolia') in India associated with similar dieback symptoms (Rao et al., 2011) and axillary shoot proliferation (Verma et al., 2012); and group 16SrXII 'Stolbur' associated with a dieback-like disease of papaya in Israel (Gera et al., 2005), and yellows disease in Taiwan (Bau et al., 2011). To our knowledge, this is the first record of the identification of a 16SrI ' $\mathrm{Ca}$. Phytoplasma asteris' isolate associated with a dieback-like disease of papaya in Sri Lanka. This finding demonstrates significant phytosanitary impact for the papaya industry in Sri Lanka, and the region, considering that $16 \mathrm{SrI}$ is the group that possesses the widest plant host range and the most complex epidemiology worldwide.

\section{Acknowledgements}

The authors acknowledge the research grant (Pro/DVC/0185) received through the TURIS project from University of Ruhuna, Sri Lanka.

\section{References}

Acosta K, Zamora L, Fernandez A, Martinez Y, Santos ME, Mendez J, Chávez A, Leyva NE, 2011. First report of 'Candidatus Phytoplasma sateris' (group 16SrI) affecting papaya in Cuba. New Disease Reports 24, 29. http://dx.doi.org/10.5197/j.2044-0588.2011.024.029

Bau HJ, Hung SC, Chang WC, Chen YK, 2011. First report of Group 16SrXII phytoplasma associated with papaya yellows in Taiwan. Plant Disease 95, 1581. http://dx.doi.org/10.1094/PDIS-05-11-0407

Dickinson M, Tuffen M, Hodgetts J, 2013. The phytoplasmas: An introduction. Methods in Molecular Biology (Phytoplasma: Methods and Protocols) 938, 1-14. http://dx.doi.org/10.1007/978-1-62703-089-2 1

Gera A, Mawassi M, Zeidan A, Spiegel S, Bar-Joseph M, 2005. An isolate of 'Candidatus Phytoplasma australiense' group associated with Nivun Haamir dieback disease of papaya in Israel. Plant Pathology 54, 560. http://dx.doi.org/10.1111/j.1365-3059.2005.01236.x

Rao GP, Chaturvedi Y, Priya M, Mall S, 2011. Association of a 16SrII group phytoplasma with dieback disease of papaya in India. Bulletin of Insectology, 64 (Supplement), S105-106.

Verma R, Mungekar D, Gaikwad P, Tomer SPS, Datar VV, 2012. First report of a phytoplasma associated with an axillary shoot proliferation disease in papaya in India. New Disease Report 25, 18. http://dx.doi.org/10.5197/j.2044-0588.2012.025.018

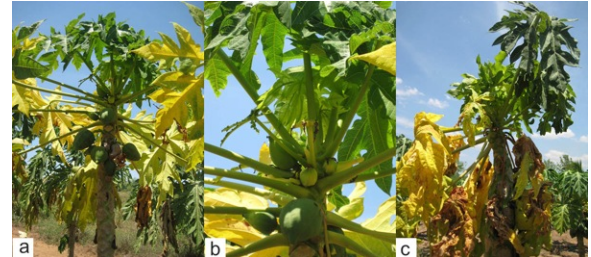

Figure 1

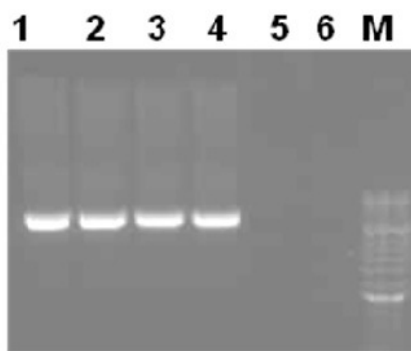

Figure 2
Figure 3

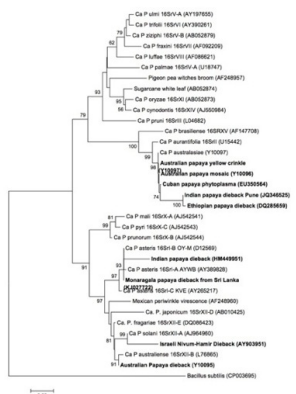

To cite this report: Abeysinghe S, Kumari WGSM, Arachchi IMM, Dickinson M, 2014. First report of the molecular identification of a phytoplasma associated with dieback disease of papaya in Sri Lanka. New Disease Reports 29, 13. http://dx.doi.org/10.5197/j.2044-0588.2014.029.013 